\title{
ROOT-END FILLING MATERIALS - REVIEW
}

\author{
Tsvetelina Borisova-Papancheva ${ }^{1}$, Vladimir Panov ${ }^{1}$, Stefan Peev ${ }^{2}$, Georgi Papanchev ${ }^{3}$ \\ ${ }^{1}$ Department of Conservative Dentistry and Oral Pathology, \\ ${ }^{2}$ Department of Periodontology and dental implantology, \\ ${ }^{3}$ Department of Oral and Maxillofacial Surgery, \\ Faculty of Dental Medicine, Medical University of Varna
}

\begin{abstract}
The aim of this study is to describe different root-end filling materials according to the literature and to compare their antibacterial activity, sealing ability, biocompatibility and microleakage. The purpose of a root-end filling is to establish a seal between the root canal space and the periapical tissues. A number of materials have been suggested for use as root-end fillings, including gutta-percha, amalgam, Cavit, intermediate restorative material (IRM), super EBA, glass ionomers, composite resins, carboxylate cements, zinc phosphate cements, zinc oxide-eugenol cements and mineral trioxide aggregate (MTA).
\end{abstract}

Keywords: root-end filling materials, sealing ability, microleakage

\section{INTRODUCTION}

The purpose of root-end filling material is to hermetically seal the apex $(1,2)$. It has to prevent the residual irritants and oral contaminants from exiting the root canal system and entering the periradicular tissues. The ideal root-end filling material would have the following characteristics $(1,3,19)$ :

* Adhere and adapt to the walls of the root preparation

* Prevent leakage of microorganisms and their products into the periradicular tissues

* Be biocompatible

* Nonresorbable

* Unaffected by moisture

* Easy to prepare and place

\section{Address for correspondence:}

Tsvetelina Borisova-Papancheva

Department of Conservative Dentistry and Oral Pathology

Faculty of Dental Medicine, Medical University of Varna

150 Tsar Osvoboditel blvd.

phone: +35952 677234

e-mail:dr_borisova@abv.bg

Received: January 15, 2015

Accepted: May 19, 2015
* Radiographically visible

* To have anticaries activity

* To be non-toxic, non-carcinogenic, dimensionally stable

* It should not cause paresthesia

* It should not cause additional pigmentation

* It should not corrode or be electrochemically active

* It should have bactericidal or bacteriostatic effect

* It should stimulate cementogenesis

* It should be well tolerated by periradicular tissues with no inflammatory reactions

Surgical endodontic therapy is the treatment of choice when teeth have responded poorly, when inadequate instrumentation is met and teeth cannot be treated nonsurgically. When the root-end preparation has been completed, the proper root-end filling material is inserted. There are numerous rootend filling materials but no material has been found to fulfill all the properties for ideal retrograde filling. The materials which are most commonly used are given below. 
One of the materials which is very often used is the amalgam. Other metals such as gold-foil, silver posts, tin posts, titanium screws and gallium alloy are also commonly used.

Cements such as Super EBA, IRM, glass iono-mers, carboxylate cements, zinc phosphate cements, Diaket, zinc oxide-eugenol cements and mineral tri-oxide aggregate (MTA) are also used for retrograde filling.

Other materials which are widely used are composite resins and gutta-percha.

Root-end filling materials which are used rarely are laser, citric acid demineralization, teflon, ceramic inlay.

A wide variety of materials have been used for retrograde fillings (Tabl.1).

\section{Tabl.1.}

\begin{tabular}{lc}
\hline Plastic materials & Rigid materials \\
Amalgam & Titanium inserts \\
GIC & Ceramic inserts \\
$\begin{array}{l}\text { Zincoxide eugenol } \\
\text { cements (IRM, super } \\
\text { EBA, Cavit) } \\
\text { Composite resin/dentine } \\
\text { adhesive }\end{array}$ & Silver points \\
Biodentine & Gold-foil \\
MTA & Gallium alloy \\
Gutta-percha & Ceramic inlay \\
Diaket & \\
Bioaggregate & \\
Zinc phosphate & \\
\hline
\end{tabular}

\section{AMALGAM}

Silver amalgam is one of the most commonly used root-end filling material. It remains as a standart to which other materials are compared. One of the first reports of placing amalgam as a root-end filling is attributed to Farrar (1884). Clinical and histopathological studies show that amalgam, implanted subcutaneously and adjacent to bone is well tol- erated by periapical tissues $(22,38)$. Amalgam is easy to manipulate, has good radioopacity and is nonsoluble in tissue fluids, because of the formation of corrosion products. The preferred amalgam is high copper-zinc free.

Anderson et al. (8) reported that using a bonding agent (4-META) with the amalgam significantly reduces the microleakage of the amalgam retrograde fillings.

Zhu et al. (58) suggested that amalgam had a higher cell toxicity to human periodontal ligament cells and human osteoblast-like cells than IRM and Super-EBA. Makkawy HA et al. found (29) that use of resin-modified glass ionomer cement as a root perforation repair material initially $(<24 \mathrm{~h})$ may result in a more favorable response by PDL cells than the tested dental amalgam.

Studies by Tronstad et al. (51) and Abdal et al. (4) have found that the apical seal is significantly improved when varnish was applied to the cavity prior to the placement of a retrograde amalgam filling. Other comparative studies (52) showed that freshly mixed conventional amalgams are very cytotoxic due to unreacted mercury with cytotoxicity decreasing as the material hardens. Georgiev et al. (24) reported a clinical case of paresthesia due to disseminated amalgam retrograde filling in the upper jaw and soft tissues.

The problems with amalgam are:

1. It produces corrosive by-products $(15,28,43)$.

2. As a result of metal's primary shrinkage it initially leaks.

3. There is a possibility of mercury and tin contamination.

4. It is moisture sensitive.

5. A retentively designed cavity preparation is required for retention.

6. It may cause tissue tattooing $(15,29)$.

7. Scattered particles are not resorbable and may be difficult to retrieve.

8. It does not seal the root end three-dimensionally and does not prevent the leakage of microorganisms and their products in the periradicular tissues $(15,24,40)$. 
Tsvetelina Borisova-Papancheva, Vladimir Panov, Stefan Peev et al.

9. Many surveys based on clinical studies have reported poor outcomes with amalgam used as a root-end filling material $(15,40)$.

\section{ZINC OXIDE}

The most commonly used zinc oxide cements are Super EBA and IRM. IRM is $80 \%$ zinc oxide, $20 \%$ polymethylmethacrylate, with the liquid being $99 \%$ eugenol. Super EBA is $60 \%$ zinc oxide, $30 \%$ alumina, $6 \%$ natural resin, with the liquid being $37.5 \%$ eugenol and $62.5 \%$ orf/ 70 -ethoxybenzoic acid. These cements have excellent sealing capability and are non toxic after setting.

The use of Super EBA of root-end filling material was suggested by Oynick and Oynick (39) in 1978. They reported that collagen fibers grew over Super EBA root-end fillings and claimed the material to be biocompatible.

Baek et al. (10) compared the periapical tissue responses and cementum regeneration in response to three widely used root-end filling materials, amalgam, SuperEBA, and Mineral Trioxide Aggregate (MTA) and found that Super EBA was superior to amalgam as a root-end filling material.

Torabinejad $\mathrm{M}$ et al. (47) examined the tissue reaction of implanted Super-EBA and MTA in the mandibles of guinea pigs. Two bony cavities without implanted materials were left to heal and used as negative controls. The presence of inflammation, predominant cell type, and thickness of fibrous connective tissue adjacent to each implant was recorded. Based on these results, it seems that both Super-EBA and MTA are biocompatible.

Pitt Ford TR et al. (41) examined the effect of Super-EBA cement as a root-end filling placed in eight molar roots in monkeys. The tissue response to Super-EBA was very mild, with only a few inflammatory cells being observed at the root end of 3 of the 8 roots filled. It is concluded that the tissue response to Super-EBA as a root-end filling is acceptable and considerably more favorable than that to amalgam.

Pitt Ford TR et al. (42) examined also the effect of IRM root end fillings on healing after replantation in 21 molar teeth in monkeys and concluded that the tissue response to root-end fillings of IRM in replanted teeth was less severe and less extensive than that to amalgam.
Harikaran et al. (27) evaluated the sealing ability of tree different materials for retrograde filling and revealed that the dye leakage scores were lowest in IRM. The sealing ability of IRM was significantly better than amalgam and glass-ionomer.

Trope et al. (53) in a histological study confirmed the good tissue response to both EBA and IRM.

Super EBA adheres well to itself and can be added incrementally as necessary but IRM does not. Reports (39) showed a good healing response to super EBA with minimal chronic inflammation at the root apex. EBA demonstrates no leakage $(10,26)$.

These zinc oxide cements have the following disadvantages:

1. They are moisture sensitive.

2. They cause initial tissue irritation.

3. Resorbability is questionable.

\section{GLASS IONOMER CEMENT}

Glass ionomers are formed by the reaction of calcium-aluminosilicate glass particles with aqueous solutions of polyacrylic acid. It bonds physicochemically to dentine. These cements are easy to handle and does not cause any adverse histological reaction in the periapical tissue $(13,32)$. Chong et al. (14) used light cure, resinreinforced GIC as a retrograde filling material. It showed least microleakage due to less moisture sensitivity, less curing shrinkage and deeper penetration of polymer into dentin surface. According to MacNeil K et al. (34) sealing ability of GIC was adversely affected when the root end cavities were contaminated with moisture at the time of placement of cement.

It is reported that newer glass ionomer cements containing glass-metal powder have less leakage and showed no pathologic signs (57).

The glass ionomers have the following disadvantages:

1. The root preparation must be absolutely dry.

2. The seal is adversely affected by moisture and low $\mathrm{PH}$.

\section{GUTTA-PERCHA}

Gutta-percha is the most commonly used material for retrograde and orthograde filling. It has to obtain a hermetic seal coronally and apically. Orthograde gutta-percha root canal obturation that is as- 
sociated with apical surgery is burnished after apicoectomy with either cold or hot burnisher. Abdal and Retief (4) in their study observed that heat sealed gutta-percha provides a better seal as compared to Amalgam, IRM and Super EBA. It is reported that a better seal can be obtained with thermo-plasticized gutta-percha than amalgam with and without varnish $(35$ 55,56).

Although this nonresorbable, biocompatible material has good handling characteristics it has the following disadvantages:

1. It is moisture sensitive.

2. The apical seal depends on the structure of the gutta-percha, its degree and condensation, and the nature and amount of root canal sealer used.

3. There is a tendency for its margins to open when the canal root interface is cut, heated or burnished.

\section{CAVIT}

It is a Zinc oxide based temporary filling material. Cavit is soft when placed in the tooth and subsequently undergoes a hygroscopic set after permeation with water, giving a high linear expansion (18\%). This rationalizes its use as a root-end filling material. Cavit has been shown to exhibit greater leakage than IRM (23). It is not proved that it is toxic or non-toxic that is why using Cavit is not recommended as retrograde filling $(6,54)$.

\section{COMPOSITE RESIN}

Composite resins are used with a bonding agent as a retrograde filling. Rud et al.(44) have reported on several prospective and retrospective human usage studies in an attempt to evaluate the acceptability of composite resin combined with a dentin-bonding agent as a retrograde filling. They applied Gluma in vivo to cases requiring periradicular surgery and compared it to cases treated with root-end amalgam fillings. Gluma exhibited complete healing in $74 \%$ of the cases as compared to amalgam - healing only in $59 \%$ of cases. In another study Rud et al. (45) demonstrated excellent long term clinical success with the use of retroplast composite resin and Gluma bonding agent.

Using composite resin for retrograde filling allows for more conservative preparation of the rootend cavity. Rud et. al (45) have suggested a slightly concave root-end preparations followed by bonding to the entire resected root end.

Some authors have reported that some composite resins have cytotoxic effect that may persist 30 days or longer (7).

MINERAL TRIOXIDE AGGREGATE (MTA)

It was developed by Torabinejad at Loma Linda University, CA, USA in 1993. The main molecules present in MTA are calcium and phosphorous ions, derived primarily from tricalcium silicate, tricalcium aluminate, tricalcium oxide and silicate oxide. Its $\mathrm{pH}$ when set is 12.5 and its setting time is 2 hours and 45 minutes. The compressive strength of MTA is reported to be $40 \mathrm{MPa}$ immediately after setting and increases to 70MPa after 21 days (48).

MTA has been extensively evaluated for microleakage, marginal adaptation and biocompatibility. MTA sealing ability has been shown to be superior to that of super EBA and was not affected by blood contamination.

Several dye leakage studies have demonstrated the fact that MTA leaks significantly less than other root-end filling materials. Fischer et al. (21) determined the time needed for Serratia marcescens to penetrate a $3 \mathrm{~mm}$ thickness of zinc-free amalgam, Intermediate Restorative Material (IRM), Super-EBA, and MTA when these materials were used as rootend filling materials. The number of days required for $S$. marcescens to penetrate the four root-end filling materials and grow in the phenol red broth was recorded and analyzed. They reported that most of the samples filled with zinc-free amalgam leaked bacteria in 10 to 63 days. IRM began leaking in 28 to 91 days. Super-EBA began leaking in 42 to 101 days. MTA did not begin leaking until day 49. At the end of the study, four of the MTA samples had not exhibited any leakage. Statistical analysis of the data indicated Mineral Trioxide Aggregate to be the most effective root-end filling material against penetration of $S$. marcescens.

Apaydin et al. (9) compared the effect of fresh MTA with set MTA on hard-tissue healing after periradicular surgery in the root canals of 24 mandibular premolars in four 2-yr-old beagle dogs . They found that there is no significant difference in the quantity of cementum or osseous healing associated with 
Tsvetelina Borisova-Papancheva, Vladimir Panov, Stefan Peev et al.

freshly placed or set MTA when used as root-end filling material.

Lindeboom et al. (33) performed a randomized clinical prospective study to evaluate the application of MTA and IRM as retrograde sealers in surgical endodontics. One hundred single-rooted teeth were surgically treated. After randomization, MTA or IRM was used as a retrosealer. Radiographs were taken 1 week, 3 months, and 1 year postoperatively. Complete healing was observed in $64 \%$ of the MTAtreated teeth vs $50 \%$ of the IRM-treated teeth. Incomplete healing was seen in $28 \%$ (MTA) vs $36 \%$ (IRM), and unsatisfactory in 6\% (MTA) vs 14\% (IRM). Only 1 failure was seen (MTA). No statistically significant differences were found between the 2 retrofilling materials.

The marginal adaptation of MTA was better with or without finishing when compared to IRM and Super EBA (25). MTA, when used as a root-endfilling material, showed evidence of healing of the surrounding tissues $(46,49,50)$. Most characteristic tissue reaction of MTA was the presence of connective tissue after the first postoperative week (20).

\section{CONCLUSION}

Nowadays no material has been found that meets all of the requirements of an ideal root-end filling material. The authors have successfully used Super EBA and IRM for over 30 years. Based on the literature and dental studies, dental amalgam should no longer be used because of its poor marginal adaptation, cytotoxic effect and inadequate sealing. MTA remains to be the material of choice because it is nontoxic, non-carcinogenic, biocompatible, dimensionally stable and has high radioopacity, good tissue tolerance and possible induction of mineral tissue (49).

\section{REFERENCES}

1. Ingle JI, Leif $\mathrm{K}$, Bakland, JC Baumgartner. Ingle's Endodontics 6. Hamilton: BC Decker Inc; 2008. pp 1233-1294.

2. Cohen S, Burns R. Pathways of the Pulp. $6^{\text {th }}$ ed. Mosby-Year Book; 1994. pp 531-568.

3. Arens DE, Torabinejad M, Chivian N, Rubinstein R. Practical Lessons in Endodontic Surgery. Quintessence Publishing; 1998. pp 121-123.
4. Abdul K, DH Retief, HC Jamison. The apical seal via the retrosurgical approach. II. An evaluation of retrofilling materials. Oral Surg. 1982:54:213-8.

5. Aggarwal V, Singla M, Miglani S, Kohli S. Comparative evaluation of push-out bond strength of ProRoot MTA, Biodentine, and MTA Plus in furcation perforation repair. Journal of conservative dentistry: JCD. 2013;16(5):462.

6. Al-Nazhan S, Sapounas G, Spangberg LSW. In vitro study of the toxicity of a composite resin, silver amalgam and cavit. J Endod. 1988;14:236-8.

7. Andreasen J, Munksgaard E, Fredebo L, Rud J. Periodontal tissue regeneration including cementogenesis adjacent to dentin-bonded retrograde composite fillings in humans. J Endod.1993;19:151-3.

8. Anderson RW, Pashley DH, Pantera

EA.Microleakage of amalgam bond in endodontic retrofillings. J Endod. 1991;1:63-5.

9. Apaydin ES, Shabahang S, Torabinejad M. Hardtissue healing after application of fresh or set MTA as root-end-filling material. J Endod. 2004;30:21-24.

10. Baek SH, Plenk H Jr, Kim S. Periapical tissue responses and cementum regeneration with amalgam, SuperEBA, and MTA as root-end filling materials. J Endod. 2005;31:444-449.

11. Bernabé PFE, Gomes-Filho JE, Galera B, Juvenal N, Arlindo Otoboni-Filho, Dezan-Jr, Angelo C. Sealing Ability of MTA Used as a Root End Filling Material: Effect of the Sonic and Ultrasonic Condensation. Braz. Dent. J. 2013;24(2):107-10.

12. Beltes $P$, Zervas $P$, Lambrianidis $T$, Molyvdas I. In vitro study of the sealing ability of four retrograde filling materials. Endont Dent Traumatol. 1988;4:82-4.

13. Callis PD, Santini A. Tissue response to retrograde root fillings in the ferret canine: A comparison of glass ionomer cement and gutta percha with sealer. Oral Surg. Oral Med Oral Pathol. 1987;64:475-9.

14. Chong BS, Pittford TR, Watson TF. The application and sealing ability of light-cured glass ionomer retrograde fillings. Int Endod J. 1991;24:223-32.

15. Chong BS, Ford TRP. Root-end filling materials rationale and tissue response. Endodontic Topics. 2005;11:114-130.

16. Damas BA, Wheater MA, Bringas JS, Hoen MM. Cytotoxicity comparison of mineral trioxide ag- 
gregates and EndoSequence bioceramic root repair materials. J Endod. 2011;37:372-375.

17. Dimitrova I, Y Kuzmanova. Mineral trioxide aggregate(MTA). Clinical application. II part- ortograde and retrograde obturation of root canals, injuries and resorptive processes. Dental medicine. 2011;93(1):56-68.

18. Dimitrova I, Y Kuzmanova. Mineral trioxide aggregate(MTA). Clinical application. III partproblems of recovering perforations. Dental medicine. 2012;94(1):28-38.

19. Dorn SO, Gartner AH. Advances in endodontic surgery. Dent. Clin.Amer. 1992;36:357-379.

20. Economides N, Pantelidou O, Kokkas A, Tziafas D. Short-term periradicular tissue response to mineral trioxide aggregate (MTA) as root-end filling material. Int Endod J. 2003;36:44-48.

21. Fischer E, Arens D, Miller C. Bacterial leakage of mineral trioxide aggregate as compared with zincfree amalgam, intermediate restorative material and Super-EBA as a root-end filling material J Endod. 1998; 24:176-179.

22. Flanders H, Garth A, Burch B, Dockum N. Comparative histopathologic study of zincfree amalgam and Cavit in connective tissue of the rat. J Endod. 1975;1:56-59.

23. Friedman S, Shani J, Stabholz A, Kaplawi. Comparative sealing ability of temporary filling materials evaluated by leakage of radio sodium. Int Endod J. 1986;19:187-93.

24. Georgiev T, Peev S, Papanchev G, Borisova-Papancheva Ts, E Aleksieva. A clinical case of paresthesia due to amalgam retrograde filling disseminated in the upper jaw and soft tissues. Scripta Scientifica Medica. 2012;44(2):97-101.

25. Gondim E, Zaia AA, Gomes BPFA, Ferraz CCR, Teixeira FB, Souza-Filho FJ. Investigation of the marginal adaption of root-end filling materials in root-end cavities prepared with ultrasonic tips. Int Endod J. 2003;36:491-499.

26. Gutmann JL, Harrison JW. Surgical Endodontics Chennai: Chennai, All India Publishers and distributors. 1999. pp 230-63.

27. Harikaran K, Narayanan L. Evaluation of two different root-end preparations. JIADS. 2010;3:01-06.

28. Hohenfeldt PR, Aurelio JA, Gerstein H. Electrochemical corrosion in the failure of apical amal- gam. Report of two cases. Oral Surg Oral Med Oral Pathol. 1985;60(6):658-60.

29. Kauzman A, M Pavone, N Blanas, G Bradley. Pigmented Lesions of the Oral Cavity: Review, Differential Diagnosis, and Case Presentations. J Can Dent Assoc. 2004;70(10):682-3.

30. Kokate SR, Pawar AM. An in vitro comparative stereomicroscopic evaluation of marginal seal between MTA, glass inomer cement and biodentine as root end filling materials using $1 \%$ methylene blue as tracer. Endodontology. 2012;24(2):36-42.

31. Lee JH, Shon WJ, Lee W, Baek SH. The effect of several root-end filling materials on MG63 osteoblast-like cells. J Korean Acad Conserv Dent. 2010;35:222-228.

32. Lehtinen $\mathrm{R}$. Tissue reaction of a glassionomer cement in the rat: a possible material for apicectomy using retrograde filling. Int J Oral Surg. 1985;14:105.

33. Lindeboom JA, Joost WFH, Frans K, Akker H A. comparative prospective randomized clinical study of MTA and IRM as root-end filling materials in single-rooted teeth in endodontic surgery. Oral Surg Oral Med Oral Pathol. 2005;100:495-500.

34. MacNeil K, Beatty R. Ketac silver and Fugi II asreverse fillings: a dye study Dent Res 1987;66:297.

35. MacPherson MG, Hartwell GR, Bondra DL, Weller $\mathrm{RN}$. Leakage in vitro with high-temperature theroplaticized gutta-percha, high copper amalgam and warm gutta percha when used as retrofilling material. J Endod. 1989;15:212-5.

36. Ma J, Shen Y, Stojicic S, Haapasalo M. Biocompatibility of two novel root repair materials. J Endod. 2011;37:793-798.

37. Makkawy HA, Koka S, Lavin MT, Ewoldsen NO. Cytotoxicity of root perforation repair materials. J Endod. 1998 Jul;24(7):477-9.

38. Marcotte L, Dowson J, Rowe N. Apical healing with retrofilling materials amalgam and gutta-percha. J Endod. 1975;1(2):63-5.

39. Oynick J, Oynick T. A study of a new material for retrograde fillings. J Endod. 1978 4(7):203-6.

40. Pereira CL, MS Cenci, FF Demarco. Sealing ability of MTA, Super EBA, Vitremer and amalgam as root-end filling materials. Braz Oral Res; 2004;18(4):317-21.

41. Pitt Ford TR, Andreasen JO, Dorn SO, Kariyawasam SP. Effect of super-EBA as a root end fill- 
Tsvetelina Borisova-Papancheva, Vladimir Panov, Stefan Peev et al.

ing on healing after replantation. J Endod. 1995 Jan;21(1):13-5.

42. Pitt Ford TR, Andreasen JO, Dorn SO, Kariyawasam SP. Effect of IRM root end fillings on healing after replantation. J Endod. 1994 Aug;20(8):381-5.

43. Pleva J. Corrosion and Mercury Release from Dental Amalgam. Journal of Orthomolecular Medicine. 1989;4(3):141-158.

44. Rud J, Munksgaard EC, Andreasen JO, Rud V, Asmussen E. Retro grade filling with a composite and a dentin bonding agent. 1. Endont Dent Traumatol. 1991;7(3):118-25.

45. Rud J, Rud V. Long-term evaluation of retrograde root filling with dentin-bonded resin composite. J Endod. 1996;22:90-3.

46. Torabinejad M, Hong CU, Lee SJ, Monsef M, Pitt Ford TR. Investigation of mineral trioxide aggregate for root-end filling in dogs. J Endod. 1995;21:606-8.

47. Torabinejad M, Hong CU, Pitt Ford TR, Kaiyawasam SP. Tissue reaction to implanted SuperEBA and mineral trioxide aggregate in the mandible of guinea pigs: a preliminary report. J Endodon 1995;21:569-571.

48. Torabinejad M, Hong CU, McDonald F, Pitt Ford TR.Physical and chemical properties of a new rootend filling material. J Endod. 1995:21:349-353.

49. Torabinejad M, Pitt Ford TR. Root end filling materials-a review. Endodont Dent Traumotol. 1996;12:161-178.

50. Torabinejad M, Wilder Smith P, Pitt Ford TR. Comparative investigation of marginal adaptation of mineral trioxide aggregate and other commonly usedroot end filling materials. J Endod. 1995;21:295-99.

51. Tronstad L, Trope M, Doering A, Hasselgren G. Sealing ability of dental amalgams as retrograde fillings in endodontic therapy. J Endod. 1983;8:551-553.

52. Tronstad LA, Wenneberg D. In vitro assessment of the toxicity of filling materials. Int End J. 1980;13:131-138.

53. Trope M, Lost C, Schmitz HJ, Friedman S. Healing of apical periodontitis in dogs after apicoectomy and retrofilling with various filling materials Oral Surg Oral Med Oral Pathol. 1996;81:221-228.
54. Wennberg A, Hasselgren A. Cytotoxicity evaluation of temporary filling material. Int Endod J. 1981;14:121-4.

55. Woo YR, Wassel RW, Foreman PC. Evaluation of sealing properties of $700 \mathrm{C}$ thermoplasticized gutta-percha used as a retrograde root filling. Int Endod J. 1990;23:107-12.

56. Wu MK, Dean SD, Kersten HW. A quantitative microleakage study on a new retrograde filling technique. Int Endod J. 1990;23:245-9.

57. Youngson CC, Gly Jones J, Grieve AR. Marginal leakage associated with three posterior resin materials. J Dent Res. 1987;66:898.

58. Zhu Q, Safavi KE, Spangberg LS. Cytotoxic evaluation of root-end filling materials in cultures of human osteoblast-like cells and periodontal ligament cells. Endod. 1999 Jun;25(6):410-2. 